\title{
Dayah Darussalam Network and Dayah Awakening in Aceh
}

\author{
Mizaj \\ Ar-Raniry State Islamic University of Aceh \\ Email: mizaj@ar-raniry.ac.id
}

\begin{abstract}
As the oldest educational institution in Southeast Asia, dayah has not received wide attention from researchers at international, national and even local levels. This paper was carried out to see the revival of Dayah in Aceh through the spread of the Dayah Darussalam network. Previously the dayah had passed the phase. First, the initial phase. This phase is marked by the establishment of Dayah Zawiyah Cot Kala in the 10th century AD. Second, the golden phase. This phase occurs around the 16-18th century. This golden phase was marked by the establishment of Dayah Manyang Baiturrahman. Third, the phase of decline. This phase began since the Dutch launched their aggression in Aceh in 1873. The phase of the decline of the dayah is marked by two things: (1) the dayah scholars split their focus between conducting educational activities and physical resistance to expel the Dutch colonizers; (2) the dayah curriculum at that time began to be limited only to religious studies. And finally the phase of the Dayah awakening marked by the spread of the Dayah Darussalam network. This can be seen from the four generations who have studied in the Dayah Darussalam. The four generations formed the Dayah Darussalam network by establishing a dayah after they finished learning in the Dayah Darussalam.
\end{abstract}

Keywords:dayah; Dayah Darussalam; Dayah Manyang; Aceh

\section{Introduction}

Dayah is the name of the Acehnese for Islamic boarding schools. The word dayah itself comes from Zawiyah Arabic which literally means corners. Pojokan Nabawi mosque where the Prophet used to convey religious advice to friends. Furthermore, the word zawiyah becomes a dayah due to the strong Arab influence in Aceh (Amiruddin, 2010; Ali Hasjmy, 1978; Ismuha, 1996). In Java the term "dayah" is not known, which is known only as Islamic boarding school.

But in terms of function and usefulness, dayah can be compared to Islamic boarding schools that are spread on the island of Java.The Dayah is at the center of discussions about Islamic education in the context of past and present Acehnese society. The existence of dayah as the center of Islamic education in the past which has produced a number of ulamas and influential figures in their time is undoubted. The past Acehnese leaders like Sultan Iskandar Muda are dayah alumni (Amiruddin, 2003). The past dayah has successfully integrated general education with religious education. This can be seen from the output produced by dayah not just scholars, but also produces influential politicians or statesmen and experts in various other 
scientific fields. This is all due to the fact that dayah education was not a dichotomy of science (Said, 1981).Admittedly, the dayah institution itself experienced very significant ups and downs, especially during the Dutch colonial period. The destruction of the dayah and all its scientific treasures, libraries and manuscripts and the dayah leaders themselves had influenced the years of decline of the dayah after the Dutch colonials began to invade Aceh in 1873. Dayah and the dayah leaders were symbols and driving forces of the struggle against colonialism in Aceh (Amiruddin, 2003, Reid, 1979).Dayah as the origin of the oldest Islamic education in Southeast Asia has not received proper attention from among international and national researchers. Famous researchers such as Anthony Reid (1979, 2004, 2006, 2009), Denys Lombard (2006), Edward Espinal (2009), Karel A. Steenbrink (1974), Robert W. Hefner (2009) and R. Michael Feener ( 2013) does not mention the strategic role of dayah in political development and social change in Aceh and Southeast Asia. While at the national level, writings such as Zamakhsyari Dhofir's (1994) Pesantren Traditions and others forget completely the existence of Dayah in the history of education in the archipelago, especially in Southeast Asia.At the local level, Ali Hasjmy and Ismuha belonged to intellectuals who had adequate attention to dayah in the local and international political arena. Ali Hasjmy has provided very valuable and unique information about the role of dayah in political lines and social change as the development of dayah in Aceh's history, both in the early stages of its development or during its era.Besides Ali Hasjmy and Ismuha, Hasbi Amiruddin also wrote many studies on dayah. But from his works relating to the dayah, Hasbi Amiruddin did a lot of criticisms and recurizationof dayah education. So it can be said that no writer has yet been found who gives comprehensive attention in studying the rise of dayah at this time. This research itself aims to study the rise of dayah in Aceh through the dissemination of the Labuhan Haji alumni network to all corners of Aceh. But before arriving at this purpose, the author first explained about the ups and downs of the development of dayah in the course of Aceh's history. For this purpose the author divides the development period of dayah into three phases of development. (1) the initial period; (2) golden age; (3) period of decline; and (4) revival.

\section{Phases of Dayah Development}

\subsection{Early Phase: Dayah Cot Kala (10 M)}

Dayah Cot Kala is known as the first dayah in Southeast Asia. At this dayah taught religious and general knowledge at once. This is because at that time dayah was the only educational institution in Aceh. The dayah function at that time was still an institution to Islamize the community around the dayah and to maintain the practice of Islam by the Acehnese who had converted to Islam at that time. Because of that, Cot Kala Dayah focuses more on practical materials, especially monotheism, jurisprudence and Sufism.But when the role of Dayah Cot Kala had begun to become involved in fulfilling the interests of the Peureulak Kingdom, its function changed to a greater extent and included general sciences, religion and other practical skills. Among the sciences taught at Cot Kala Dayah are science of jurisprudence, monotheism, mysticism, geography, history, state administration and Arabic (Ali Hasjmy, 1978). At that time, the sultans who ruled the Islamic Kingdom of Peureulak consisted of scholars who had extensive 
knowledge. This was the main factor that supported the establishment of the Cot Kala Dayah in the late third century of hijriyah (the beginning of the 10th century AD). This Dayah was founded by a scholar named Muhammad Amin who later became known as Teugku Chiek Cot Kala. (Ali Hasjmy, 1978). After leading Dayah Cot Kala for more than ten years, Teugku Chiek Cot Kala has been named the sixth Sultan of Peureulak with the title Sultan Makhdum AlidinMalik Muhammad Amin Shah Johan Sovereign and ruled from 310 to 334 AH (922-946 AD).

In the next stage, this dayah has developed quite rapidly. These alumni from Dayah played an important role in spreading Islam throughout the region of Southeast Asia (Ali Hasjmy, 1978). In addition, Cot Kala Dayah alumni later also played a role in building alumni dayah networks that were spread throughout the archipelago. like Dayah Seureuleu, which was founded by ShaykhSirajuddin, Blang Pria Dayah, founded by Shaykh Ya'kob (550-670 H / 1155-1210 M) or better known as Teungku Chiek Balang Pria, the Rock Dayah founded by Teungku Ampon Tuan which was later appointed to become the Batu Karang Qadhi Negeri during the reign of Young King Sedia in the Islamic Kingdom of Teuming (present Tamiang) in 753-800 H / 13531398 AD, and the last Dayah Lam Keuneu'un founded by Shaykh Abdul Kan ' in 592-622 H / 1196-1225 M. (Ali Hasjmy, 1978).

\subsection{Golden Phase: Dayah Manyang Baiturrahman (16-18 M)}

Dayah education developed in accordance with the retreat of Islamic kingdoms that grew and developed in Aceh at that time. At the beginning of the establishment of the Islamic empire in Aceh (the Kingdom of Peureulak) the dayah was still in its initial state of development and only gained its glory momentum at the height of the Islamic kingdom in Aceh in power (Kesultan Aceh Darussalam). At that time dayah education was relatively well structured. Starting from elementary school level (bale), middle school (rangkang), college (dayah manyang / dayah ali) to graduate education (dayah tengku chiek). Even at that time also opened educational institutions intended for the wider community (meunasah). At that time the Kingdom of Aceh Darussalam promoted a program to eradicate illiteracy and blind knowledge. According to French records Benlieu, a French traveler who had visited Aceh in the XVII century, at that time no Acehnese were found illiterate. (Ayang Utriza Yakin, 2016). In addition, the Sultan also established state institutions that have special functions in managing the world of education. There are at least three state institutions established for this purpose. Namely: Setia Hukama Hall, Ulama Setia Hall and Ulama Association Society Hall.First, the Setia Hukama Hall. It is a science institution which is used as a gathering place for scholars (scholars) and thinkers (hukama) to discuss and develop knowledge. Second, the Setia Ulama Hall. This institution functions as an institution that takes care of educational issues and curriculum development. And thirdly, the Ulema Association Community Center, this institution is similar to research and development institutions (research and development) to solve various problems faced and the development of science.Besides having state institutions related to education and science. In its golden age, dayah education has also undergone structuring and a good level of education. In this study, the authors found there were five levels of dayah education at that time. Starting from the level of meunasah (elementary school), rangkang (junior high school), dayah (high school), dayah teungku chiek (higher education) and Baiturrahman scholarship (postgraduate education). 
First, meunasah or madrasah. It is the same starting school as elementary schools today. This institution was established in each village. In the meunasah students are taught basic knowledge such as reading and writing Arabic characters, reading the Koran, the practice of worship, morals, the pillars of Islam and the pillars of faith. The books used as dictates use the Malay language, such as the Book of Shamanism and Risālah Masā'il al-Mubtadi.Second, Rangkang . According to the provisions of the Qanun Meukuta Alam (Constitution of the Kingdom of Aceh Darussalam), in every mukim a mosque must be established. In addition to functioning as a place of worship, mosques also function as places of knowledge transfer. Students who study at each of the mukim mosques gradually increase. Moreover most of the many students who later stayed at the mosque because of the distance of the mukim mosque from their hometown. This situation encouraged the Sultanate of Aceh Darussalam when it established dormitories for distant students. The huts in the Acehnese language are called rangkang. So then this educational institution is better known as a ranking than the mukim mosque. At this level of education has begun to be taught muamalah fiqh, worship practices in a deeper form, monotheism, mysticism, Islamic history and world history. At this level books have been introduced in Arabic.Third, dayah, dayah can be compared to high schools at this time. Almost every region stands on a dayah. Sometimes there are also dayah that are centered on the mosque along with the rangkang. But most dayahstand alone outside the mosque environment, providing a main hall as a hall, which is usually used as a place to study and carry out religious routines such as five daily prayers. This is why it is now common to find in a village mosques and dayah with activities that are independent and not often related.In the dayah all lessons use Arabiclanguage books. The sciences taught include: fiqh muamalah, tauhid, tasawuf, geography, history, state administration and Arabic. In addition to the existing public dayah, there are also special dayah, such as women's dayah and so on.Fourth, Dayah Teungku Chiek. Teungku Chiek Dayah is sometimes also called the Dayah Manyang, which at the moment functions the same as the academy. Teungku Chiek Dayah is not as much as the dayah described earlier. Usually Teungku Chiek is only located in big cities.Among the subjects taught in this type of dayah are Arabic, jurisprudence, jurisprudence, constitutional law, Islamic history, general history, science of mantiq, monotheism, philosophy, mysticism, astronomy, interpretation, hadith, and others. In addition, there is also Teungku ChiekDayah which focuses on certain subject matter such as fiqh, interpretation, hadith and so on (Ali Hasjmy, 1978). Fifth, Baiturrahman Dayah or Baiturrahman Jamiah. After standing the teungku chiek dayah in various places within the Kingdom of Aceh Darussalam, then in the capital city of the kingdom (Kutaraja, Banda Aceh now) a Baiturr understanding agreement with various faculties was established. In its golden age, Jamiah Baiturrahman had seventeen faculties, namely: (1) Dār al-Tafsīr wa al-Hadìts (Faculty of Interpretation and Hadits); (2) Dar Țīb; (Medical School); (3) Dār al-Kimmiyā '(Faculty of Chemistry); (4) Dār al-Tārīkh (Faculty of History); (5) Dār al-Hisāb (Faculty of Mathematics); (6) rār al-Siyāsah (Faculty of Politics); (7) rār al-'Aqlī (Faculty of Logic Sciences); (8) Dār alZirā'ah (Faculty of Agriculture; (9) Dār al-Ahkām (Faculty of Law); (10) Dār al-Fāfäfah (Faculty of Philosophy); (11) Dār al-Fāfām (Faculty of Philosophy); ( 12) Dār al-Wizārah (Faculty of Government); (13) Dār al-Khazānah Bait al-Māl (Faculty of State Finance); (14) Dār al-Arḍh (Faculty of Earth Sciences); (15) Dār al-Naḥw (Faculty Arabic Literature; (16) Dār al- 
Mazahib (Faculty of Comparative Mazhab); and (17) Dār al-Harb (Faculty of Military Sciences).Based on the above description, the dayah reached its golden age due to two factors. First, the level of dayah education covers all levels of education from basic education to higher education. secondly, the curriculum and branches of science taught include all the knowledge needed at that time as can be seen by the formation of various faculties at the Baiturrahaman Dayah.After the Baiturrahman Dayah period, the development of the dayah became dim and declining due to the prolonged war between the Dutch and the people of Aceh. This war had a negative influence on the development of dayah education throughout Aceh.

The Dayah entered a period of decline when Aceh began fighting against the Dutch occupation in 1873. At that time the Acehnese cleric was busy carrying out physical resistance to expel the Dutch from Aceh. This caused the Acehnese clerics to abandon their duties in transferring knowledge at the dayah.In its heyday dayah focused only on education and the development of Islamic practice, but due to the Dutch occupation, the focus of dayah in the world of education was split so that the dayah also played a role in propaganda against the Dutch colonialism by echoing the spirit of jihad, martyrdom and the infidelity of cafes to Dutch invaders. We can at least see this in the books used by the dayah at that time. One of them is the book of Masailul Muhtadi, in which the book explains:

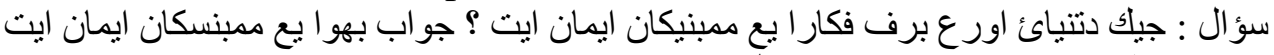

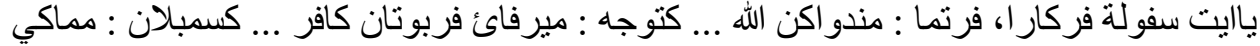

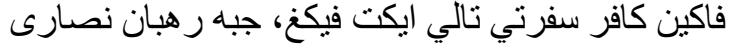

Problem: if someone is asked, how many cases destroy the faith? Answer that the one who destroyed the faith was ten things, first: to make God happy ..., the seventh to resemble the actions of unbelievers ..., ninth: to wear pagan garments like a belt, robes of Christian monks ... From the above quotation, it can be seen that the dayah scholars in this period of decline were no longer focused on education but also elaborated the teachings of religion as a weapon of resistance against Dutch colonialism.

In addition to the changing substance of the curriculum, the materials taught at dayah began to be limited to religious studies. Curriculum limitation only on religious studies was very much done by the Dutch because of Snouck C. Hurgronje's recommendations regarding the limitation of dayah and ulama movement, which was then stated in staatsblad550, 1915 (Hasbullah, 2001).The regulation aims to undermine the resistance of the ulama with their students to Dutch colonialism, while also aiming to weaken the ulama's power in society and strengthen the influence of ulee balang (Aceh aristocracy) as accomplices of the invaders. Since then the dayah curriculum has been limited to religious education which deals with the fiqh of the Shafi'i schools, the aqeedah of Asya'irah and certain tarekat such as Haddadiyah, Naqsyabandiyah, Samadiyah and Syatariyah.

\subsection{Dayah Awakening: Dayah Darussalam and its Network}

In the 21st century the dayah entered a period of resurrection. Dayah Awakening in Aceh was marked by the establishment of the Haji Labuhan Haji Darussalam South Aceh. This Dayah has produced a network of Dayah scholars throughout Aceh.

The network of Dayah Darussalam scholars has an important role in establishing dayah education in Aceh today. This is because almost all Dayah Darussalam alumni become founders 
and dayah leaders. This can be seen by tracing generations of alumni who form the Dayah Darussalam network.

\subsubsection{Profile of Abuya Muda Waly}

Labuhan Haji Dayah Darussalam was founded by Abuya Muhammad Waly who later became known as Abuya Muda Waly. He was born in Blangporoh village, Labuhan Haji subdistrict, South Aceh regency in 1917. He was the son of Shaykh Haji Muhammad Salim bin Malim Palito from Batu Sangkar, West Sumatra. While his mother Siti Janadat is a local resident.His initial education got from his father directly. While for general knowledge was taken at Volks-School (elementary school founded by the Dutch) in 1921. He also studied religion at the Al-Khairiyah school for four years. Among his teachers during the study were Abu Daud Beureueuh and Shaykh Dam from Aceh Besar. Then he was delivered to study at Bustanul Huda Dayah in Blang Pidie. A dayah who understands the Ahl Sunnah wal Jamaah led by Shaykh Mahmud from Aceh Besar.One of the major events that changed the life of Abuya Muda Waly was when an Acehnese merchant named Teuku Hasan Glumpang Payung was eager to send him to the Normal Islam School in West Sumatra at that time. Normal Islam School itself was founded by MuhmudYunus, a Muslim scholar who is an alumni of Al-Azhar and Darul Ulum Cairo, Egypt. At that time the curriculum used by Normal Islam School was the adoption of the Al-Azhar curriculum. The institution has also used the modern teaching system using chairs, tables and blackboards.During his study in West Sumatra, Abuya Muda Wali became acquainted with Shaykh SulaimanAl-Rasuli, Shaykh Muhammad Jamil Jahoo and other great scholars. His relationship with Shaykh Muhammad Jamil Jaho was initially limited to student and teacher relations. This relationship then increased to a son-in-law relationship when Shaykh Jamil Jaho put him away with his daughter Ummi Rabiah.

\subsubsection{Establishing Dayah Darussalam}

Upon returning from West Sumatra, Muda Waly took the initiative to establish the Dayah Darussalam in 1936. At the beginning of his return he saw the enthusiasm of the local community to study and study from Abuya Muda Waly. As the number of students grew, MudaWaly also took the initiative to buy a large amount of land to set up a platform as a place to live and study the students. (Majid, 2005).

In the next stage, the enthusiasm of attending school in the Dayah Darussalam did not only arise from the local population but also from other regions. Even most of them have become big scholars in their respective regions. For this special student, Muda Waly allocates special time, which usually occurs at midnight. Amran Waly - one of his sons - told about one of Waly's Young students named Habi Labay Sati, he was a great scholar of West Sumatra at the time, but then he was willing to become a Waly Young student after losing a debate in religion.In his book Our Father,. Muhibbuddin Waly (1993) describes in detail the parts contained in the Dayah Darussalam environment, namely: Darul Muttaqin, the location of schools ranging from low to high levels. Darul Arifin, the residence of teachers who are generally married. DarulMuta'allimin, home of selected students. Darul Zahidin, this place is rarely inhabited because of its unsupportive location and the last is Darul Ma'la, which is the location of the santri dormitory. This Dayah also has a higher education institution called Bustanul 
Muhaqqiqin.Some of the reforms carried out by Muda Waly in the dayah education curriculum became the model adopted by other dayah. Especially by dayahfounded by alumni of Dayah Darussalam. Among some of the new subjects contained in the curriculum are the science of Mantiq, Balaghah, Usulul Jurisprudence and so on which previously these materials have never been taught in dayah education. (Muhibuddin Waly, 1993). For teaching methods, Dayah Darussalam still uses traditional methods.Outside of political and social life, Muda Waly is a cleric who dedicates his life to the advancement of dayah education. After a student named Teungku Keumala told in his brief note entitled Waifif Abuya how all his age was spent taking care of education. His efforts were not in vain as quoted by Muhammad Ar (2013) in his book that most of the dayah leaders scattered throughout Aceh were now his students or at least students from his students. This shows that there is a network of Acehnese dayah scholars who are now widely released throughout the region in the province of Aceh. The dayah network all originates at Labuhan HajiDayah. This network can be seen from the mapping of scholars who have studied in Dayah Darussalam or students who have studied in dayah Darussalam alumni.

\subsubsection{Darussalam Dayah Network}

As revealed by Saby (2004) in his book that Dayah Darussalam is a traditional Islamic education institution that has produced prominent dayah leaders in Aceh. Abuya Muda the guardian himself was a respected figure and became teachers of other dayah ulama. When asked of one of his sons, how could it be that during his brief leadership in leading the Dayah Darussalam, he managed to produce reliable dayah scholars. It turns out that the students who study at this dayah are not people who come without any competence. Not infrequently those who come to study with Young Sheikh Waly are people who are generally considered to be scholars by the local community. But because they feel Young Shaykh Waly has more knowledge, then they do not hesitate to study with him. (interview, 20 February 2018).From the learning process this resulted in the networking of Acehnese dayah ulamas today. Many of them participated in building dayahs scattered throughout Aceh and even outside Aceh. In this study, mapping the distribution of the dayah Darussalam network can be divided into four generation categories.First generation students like Tgk. Ahmad Isa Peudada Founder of Dayah Nurul Huda Peudada, Abu Jailani Peudada, Tgk. Abdullah Hanafi (Abu Tanoh Mierah) founder of Dayah Darul Ulum Tanoeh Mierah, Tgk. Syahbuddin Panton Labue (Abu Keumala) founder of Dayah Safinatussalamah Medan, Tgk. Haji Ja'far Siddiq (Southeast Aceh), Abu Muhibbuddin Waly, founder of Dayah Nasof Lampeune, according to Tgk. Idrus Padang, Abu H. Labay Sati, Tgk. Yusuf Natural Bakongan and Tgk. Marhaban bin Abu Krueng Kale.The second generation students such as Abon Aziz Samalanga the founder of Dayah Ma'had Ulum Diniyyah Islamiyah Mesjid Raya (Mudi Mesra) and Tgk Adnan Mahmud Bakongan are the founders of Yamin Dayah Ashabul. Third generation student, Tgk. Abu TuminFinally, the fourth generation students like Abu Daud Zamzami the founder of Dayah Riyadhussalihin Blang Bintang, Tgk. Muhammad Cot Klat, Abu Muhammad bin Zamzami (Abu Ahmad Perti) the founder of Dayah Istiqamatuddin Darul Mu'arif Kuta Baroe, Tgk. Abdullah, Abu Jamaluddin Waly, founder of Dayah Asasun Najah Blang Bintang, Abu Nasir Wali, founder of Dayah Serambi, Mecca of Meulaboh, Abu Mawardy Waly, founder of Dayah Shaykh Muhammad Jamil in West Sumatra, Abu Amran Waly Dayah Darul Ihsan Pawoh Labuhan Habi and Tgk. Jamaluddin Teupin Punti. Of the many 
students of Abuya Muda Waly from every generation there were those who looked more prominent than the other students. In the first generation Tgk. Marhaban who is also the son of Abu Kreung Kale and Tgk. Abdullah Hanafi is very prominent compared to his other students.

Although Tgk. Marhaban did not establish a dayah, but his success in the political world by having served as a young minister in the Soekarno era was inseparable from the education he received. On the other hand Tgk. Abdullah Hanafi or better known as Abu Tanoeh Mierah is a student of Abuya Muda Waly who is very prominent in the science of Islamic Jurisprudence. In addition, he also founded the Dayah Darul Ulum Tanoh Mierah, known as usahuli dayah among the Aceh Dayah network.

In the second generation Abon Aziz Samalanga was the most prominent student among the other students. In addition to establishing the Dayah Ma'had Ulum Diniyah Islamiyah Mesjid Raya or better known as the Dayah Mudi Mesra. He also managed to educate his students to become great dayah clerics in Aceh. among his students were Abu Ibrahim Lamno, Abu Kuta Krueng the founders of Dayah Darul Munawarah, Abu Kasim TB, Tu Din Jakarta, Abu Lhok Nibong (Abu Lueng Angen) and Tgk. Ibrahim Bardan (Abu Pantoen Labue) the founders of DayahMalikussaleh and Abu Hasanol Basri (Abu Mudi) who were sons-in-law of Abon AzizSamalanga. After Abon Aziz. Samalanga died, the relay of the Dayah Mudi Mesra leadership was continued by his assistant Abu Mudi. In the hands of Abu Mudi Dayah Mudi Mesra, there has been a rapid development. To date, the dayah has 122 branch boarding schools and alumni spread throughout Aceh and Indonesia. The alumni's dayah and branch are usually marked by raising the name Aziziyah at the end of the name of the pesantren. Like Dayah Mahyal Ulum AlAziziyah which was founded by Tgk. Faisal Ali (Lem Faisal), Madani Dayah Al-Aziziyah founded by Abiya Hatta and Dayah Markaz Al-Islah Al-Aziziyah which was founded by Tu Bulqaini Tanjongan. Whereas in the third and fourth generation Tgk. Muhammad Amin (Tumin) and Abu Daud Zamzami appeared as students of Abuya Muda Waly, who were most prominent compared to other students. Abu Tumin founded the Dayah Al-Madinatud Diyanah BabussalamBlang Bladeh while Abu Daud Zamzami founded the Dayah RiyadusshalihinIn this study also found several factors that caused Abuya Muda Waly to have reliable students and dayahs whose systems quickly spread. Among others are:

1. Generally, the early generation of students who came to study at Abuya Muda Waly were pious people who had high knowledge and mastered the books taught in traditional dayah, even most of them had had their own Islamic schools like Abon Aziz Samalanga.

2. When Abuya Mudawali led the Labuhan Haji Dayah, in Aceh there was a DI / TII uprising led by Abu Daud Beureueh. At that time, madrasahwere generally under the care of the PUSA frontman (Aceh Dayah Ulama Association) who were pro-DI / TII fighters. This tendency resulted in the development of madrasah under their control. This resulted in the community's interest in going to school in the madrasah to drop dramatically. Instead, people prefer dayah as a place to anchor them in their studies. And the main choice of dayah at that time was Labuhan Haji Dayah.

3. Generally Abuya Muda Waly's students wished to build a dayah after they returned to their hometowns. This caused the Dayah Darussalam learning and education system to become very rapid throughout Aceh through the alumni dayah network. The main reason for the students of 
Abuya Muda Waly wanted to establish a dayah because they did not have other jobs they could do after completing the Koran at the Dayah Darussalam. So, one of the most possible job opportunities they do is to establish a dayah as a place to serve. (Focus Group Discussion, 20 February 2018). Talking about the endurance and sustainability of a dayah, we not only talk about how the dayah lives and survives from time to time, but more important than that is to see how a dayah plays a role in preserving leadership and the existence of dayah in general. If in this context the Dayah Darussalam is considered as the center, then the focus that must be seen also in examining this dayah is how this center creates peripheral dayah institutions which may at one time instead turn into the center as it seems to occur in the Mudi Mesra Dayah. This process is also possible because dayah leadership is usually leadership passed down from generation to generation. the quality of dayah education will then depend on the competencies of the generation who are holding the leadership of the dayah itself.After the death of Abuya Muda Waly, the Dayah Darussalam was led in turn by his sons ranging from Abu Muhibbuddin Waly, Abu Jamaluddin Waly, Abu Nasir Wali, Abu Mawardy Waly, Abu Amran Waly, Abu RuslanWaly and now again headed by Abu Mawardy Aly.

\section{Conclusion}

In the history of its development, dayah has experienced four phases of development. Starting from the initial phase which was marked by the establishment of Cot Kala Dayah in the 10th century AD. Then the dayah experienced its golden phase when the Kingdom of Aceh Darussalam ruled in Aceh in the 16-18th century. This was marked by the establishment of the Baiturrahman Dayah. At that time, the Kingdom of Aceh Darussalam also built several state institutions that regulate education issues. These institutions consist of the Setia Hukama Hall, the Ulama Setia Hall and the Ulama Association. In addition, at that time dayah also found a more structured form in accordance with the level of education. Basic education is in the form of meunasah, junior high school education (rangkang), senior secondary education (dayah), higher education (teungku chiek / dayah nyang) and lastly. Postgraduate education (dayah baiturrahman).After that the dayah enters a phase of decline. This phase began since Belandan attacked Aceh in 1873. There are two indicators that led to this phase being called the phase of dayah retreat. First, in this phase the dayah scholars no longer focused on the world of education, they also began to be preoccupied with the affairs of the physical struggle against the Dutch colonizers. This caused many abandoned dayah to be abandoned by Tgk and his students. Second, the dayah curriculum at that time only studied religion, while general knowledge was not studied anymore. This is inseparable from Dutch policy that wants to reduce the influence of dayah in the midst of the people of Aceh.Only after the establishment of Labuhan Haji Dayah, South Aceh, did Dayah regain its resurrection momentum. The rise of the dayah at that time was marked by the spread of the Dayah Darussalam alumni network which also established many dayah. In this study, four generations were found to have acquired knowledge in Dayah Darussalam and from these four generations also participated in building dayah scattered throughout Aceh. It is this Dayah which marks the revival of dayah in Aceh at this time. 


\section{References}

Ali Hasjmy (1978). Bunga Rampai Revolusi dari Tanah Aceh, Jakarta: Cv. Bulan Bintang.

Anthony Reid (1979). The Blood of The People: Revolution and The End of Traditional Rule in Northern Sumatra. Oxford: Oxford University Press.

Anthony Reid (2004a). Charting The Shape of Early Modern Southeast Asia, Chiang Mai: Silkworm Books.

Anthony Reid (2004b). An Indonesian Frontier: Achenese and Other Histories of Sumatra, Singapore: Singapore Press.

Anthony Reid (2006). Veranda of Violence: The Historical Background of The Aceh Problem, Singapore: Singapore Press.

Ayang Utriza Yakin (2016). Sejarah Hukum Islam Nusantara Abad XIV-XIX M, Jakarta: Kencana Prenada Media Group.

Denys Lombard (2006). The Acehnese Kkingdom During Iskandar Muda Epoch, Jakarta: Ecole Francaise d'Extreme-Orient.

Edward Espinal (2009). Islam and Nation: Separatist Rebellion in Aceh Indonesia, Stanford: Stanford University Press.

H. M. Said (1981). Aceh Sepanjang Abad, Medan: Waspada.

Hasbi Amiruddin (2003). Ulama Dayah Pengawal Agama Masyarakat Aceh, Lhokseumawe: Nadia Fondation.

Hasbi Amiruddin (2013). Menatap Masa Depan Dayah di Aceh, Banda Aceh: Yayasan Pena.

Hasbi Amiruddin (Ed.), (2010). Apresiasi Dayah Sebagai Lembaga Pendidikan Islam di Aceh, Banda Aceh: Pengurus Besar Persatuan Dayah Inshafuddin.

Hasbullah (2001). Sejarah Pertumbuhan dan Perkembangan Pendidikan Islam di Indonesia, Jakarta: PT Gramedia Widiasarana Indonesia.

Karel A Steenbrink (1974). Pesantren, Madrasah, Sekolah: Pendidikan Islam dalam Kurun Modern, Jakarta: LP3ES.

Mizaj Iskandar, Sejarah Sunni-Wahabi: Titik Temu Perbedaan dan Persamaan, (Banda Aceh: Naskah Aceh, cet. I, 2015).

Muhammad Ar (2013). Student's Attitude Toward The Teacher in Islamic Traditional School (Dayah) in Aceh, Englisia (Journal of Language, Education and Humanities.

Muhibuddin Waly (1993). Ayah Kami, Maulana Syaikh Haji Muhammad Waly Al-Khalidy, Singapore: JBW Printers \& Binders PTE LTD.

Nurchalis Majid (2005). Bilik-Bilik Pesantren: Sebuah Potret Perjalanan, Jakarta: Paramadina.

R. Michael Feener, Shari' $a$ and Social Engineering: The Implementation of Islamic Law in Contemporary Aceh, Indonesia, Oxford: Oxford University Press.

Robert W. Hefner (Ed.). (2009). Making Modern Muslims The Politics of Islamic Education in Southeast Asia, USA: University of Haiwai Press.

Tgk. Chiek Di Leupue, Masa'il al-Muhtadi li Ikhwān al-Mubtadi, (Kairo: Maktabah Musțafā alHalabī, cet. III, 1999). 